Groundwater Resources Program

Geodatabase Compilation of Hydrogeologic, Remote Sensing, and Water-Budget-Component Data for the High Plains Aquifer, 2011

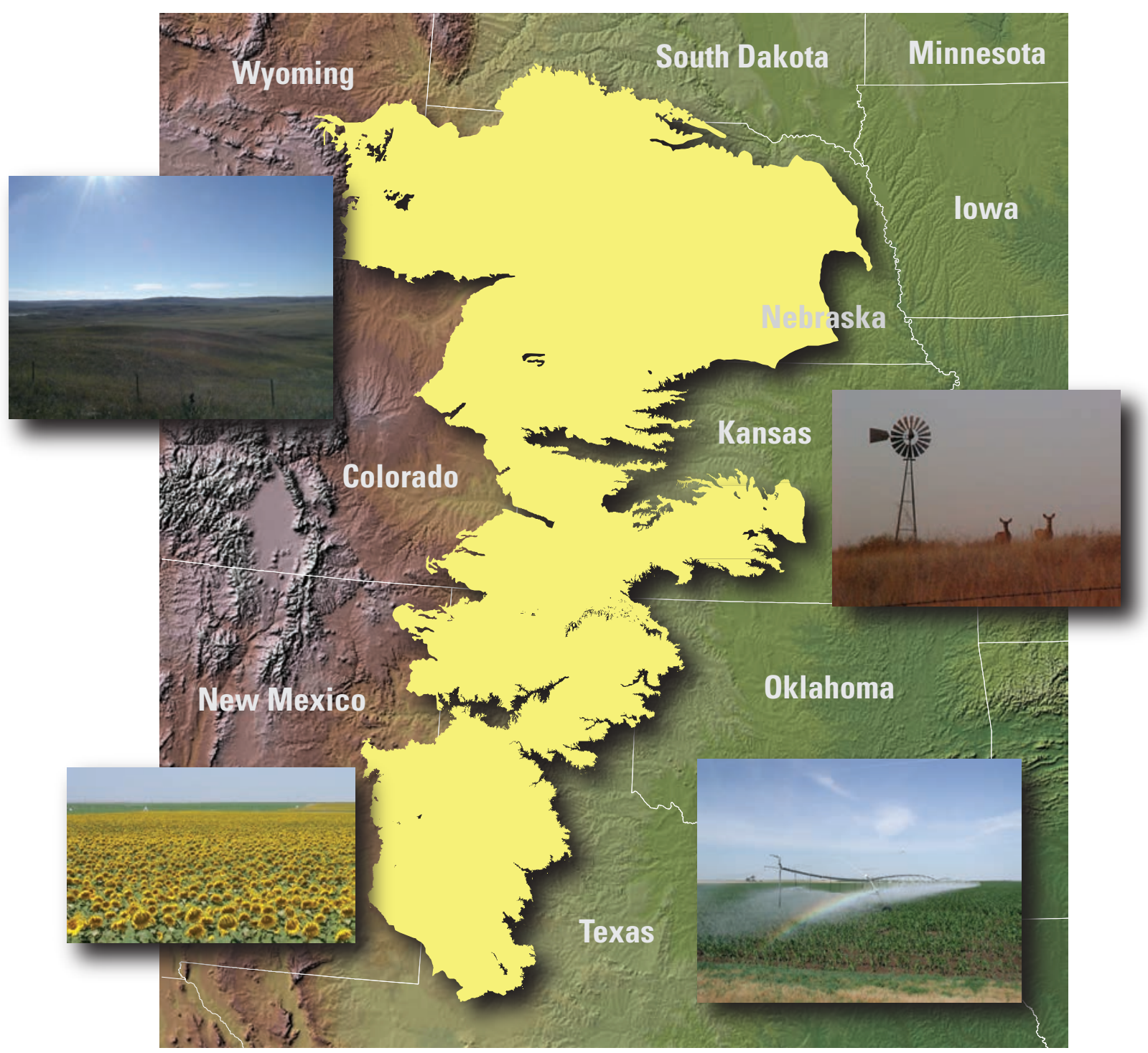

Data Series 777 


\section{Front cover:}

Top left, The rolling hills of the Nebraska Sand Hills region. Photographer: Bret Bruce, USGS.

Top right, Resident mule deer on the Nebraska High Plains. Photographer: Glen Bowers, Twin Platte Natural Resources District, Nebraska.

Bottom left, Field of sunflowers on the Texas High Plains. Photographer: Lynne Fahlquist, USGS.

Bottom right, Irrigated corn field. Photographer: Peter McMahon, USGS. 


\section{Geodatabase Compilation of Hydrogeologic, Remote Sensing, and Water-Budget-Component Data for the High Plains Aquifer, 2011}

By Natalie A. Houston, Sophia L. Gonzales-Bradford, Amanda T. Flynn, Sharon L. Oi, Steven M. Peterson, Jennifer S. Stanton, Derek W. Ryter, Terry L. Sohl, and Gabriel B. Senay

Data Series 777 


\section{U.S. Department of the Interior \\ SALLY JEWELL, Secretary}

\section{U.S. Geological Survey \\ Suzette M. Kimball, Acting Director}

\section{U.S. Geological Survey, Reston, Virginia: 2013}

For more information on the USGS — the Federal source for science about the Earth, its natural and living resources, natural hazards, and the environment, visit http://www.usgs.gov or call 1-888-ASK-USGS.

For an overview of USGS information products, including maps, imagery, and publications, visit http://www.usgs.gov/pubprod

To order this and other USGS information products, visit http://store.usgs.gov

Any use of trade, firm, or product names is for descriptive purposes only and does not imply endorsement by the U.S. Government.

Although this information product, for the most part, is in the public domain, it also may contain copyrighted materials as noted in the text. Permission to reproduce copyrighted items must be secured from the copyright owner.

Suggested citation:

Houston, N.A., Gonzales-Bradford, S.L., Flynn, A.T., Qi, S.L., Peterson, S.M., Stanton, J.S., Ryter, D.W., Sohl, T.L., and Senay, G.B., 2013, Geodatabase compilation of hydrogeologic, remote sensing, and water-budget-component data for the High Plains aquifer, 2011: U.S. Geological Survey Data Series 777, 12 p., http://pubs.usgs.gov/ds/777/. 


\section{Acknowledgments}

The authors thank the National Weather Service Office of Hydrologic Development, for providing spatial data files from the Sacramento-Soil Moisture Accounting Model.

The authors also thank Virginia McGuire, U.S. Geological Survey, Nebraska Water Science Center, for her contribution to water-level data acquired for this study and expertise related to the High Plains Water-Level Monitoring Study. Michele Bouchard, Arctic Slope Regional Corporation Research and Technology Solutions, Contractor for the U.S. Geological Survey, Earth Resources Observation and Science Center, is thanked for her contribution to the remote sensing data processed for this study and for her expertise in completing the documentation about these data. Lastly, Sarah Falk, U.S. Geological Survey, New Mexico Water Science Center, is thanked for her assistance in obtaining and reviewing spatial and tabular data used in this report. 



\section{Contents}

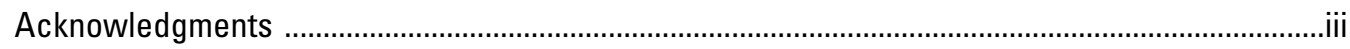

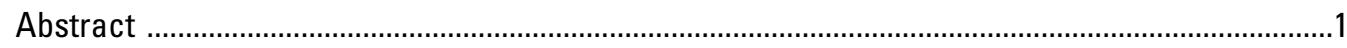

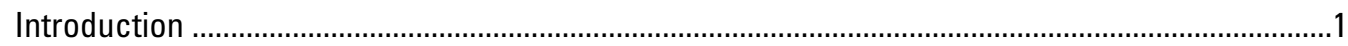

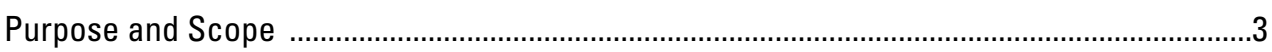

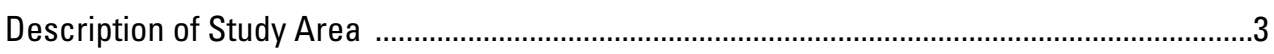

Geodatabase Compilation Methods ……………...............................................................

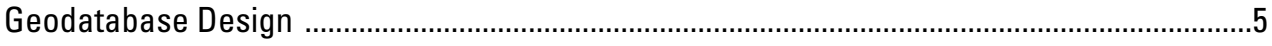

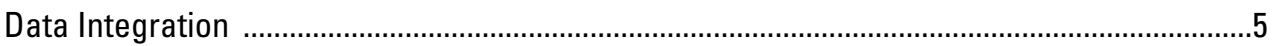

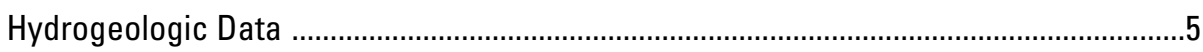

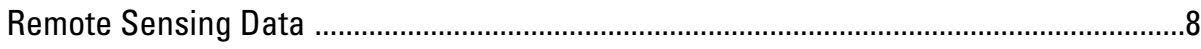

Water-Budget-Component Data ………………………………………………....

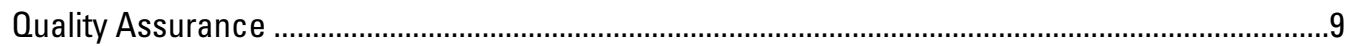

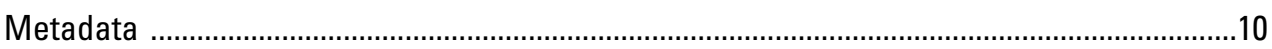

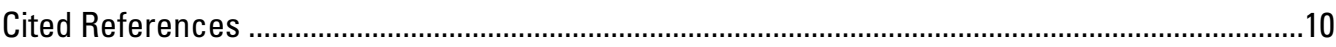

\section{Figures}

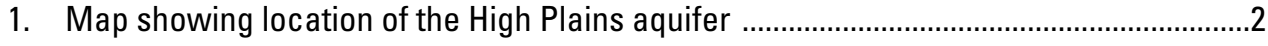

2. Map showing location of the High Plains aquifer, which is regionally divided into the northern High Plains, central High Plains, and southern High Plains aquifers ..........4

\section{Table}

1. Description and definition of data compiled and entered into the geodatabases, which are a compilation of hydrogeologic, remote sensing, and water-budgetcomponent data for the High Plains aquifer, 2011 


\section{Conversion Factors}

Inch/Pound to SI

\begin{tabular}{|c|c|c|}
\hline Multiply & By & To obtain \\
\hline \multicolumn{3}{|c|}{ Length } \\
\hline inch (in.) & 2.54 & centimeter $(\mathrm{cm})$ \\
\hline inch (in.) & 25.4 & millimeter $(\mathrm{mm})$ \\
\hline foot $(\mathrm{ft})$ & 0.3048 & meter $(\mathrm{m})$ \\
\hline mile (mi) & 1.609 & kilometer $(\mathrm{km})$ \\
\hline \multicolumn{3}{|c|}{ Area } \\
\hline acre & 4,047 & square meter $\left(\mathrm{m}^{2}\right)$ \\
\hline acre & 0.004047 & square kilometer $\left(\mathrm{km}^{2}\right)$ \\
\hline \multicolumn{3}{|c|}{ Volume } \\
\hline acre-foot (acre-ft) & 1,233 & cubic meter $\left(\mathrm{m}^{3}\right)$ \\
\hline \multicolumn{3}{|c|}{ Flow rate } \\
\hline cubic foot per second $\left(\mathrm{ft}^{3} / \mathrm{s}\right)$ & 0.02832 & cubic meter per second $\left(\mathrm{m}^{3} / \mathrm{s}\right)$ \\
\hline \multicolumn{3}{|c|}{ Precipitation, Evapotranspiration, Irrigation and Recharge } \\
\hline inches per year (in/yr) & 25.4 & millimeter (mm/yr) \\
\hline \multicolumn{3}{|c|}{ Hydraulic conductivity } \\
\hline foot per day $(\mathrm{ft} / \mathrm{d})$ & 0.3048 & meter per day $(\mathrm{m} / \mathrm{d})$ \\
\hline
\end{tabular}

Vertical coordinate information is referenced to the North American Vertical Datum of 1988 (NAVD 88).

Horizontal coordinate information is referenced to the North American Datum of 1983 (NAD 83). 


\title{
Abbreviations and Terms
}

\author{
AET \\ Base of aquifer \\ Base flow \\ BFI \\ Calibration targets \\ EROS \\ Geoparm \\ GIS \\ Hydraulic conductivity \\ IDW \\ Macro \\ MODIS \\ NWIS \\ PRISM \\ SOWAT \\ SSEB \\ SWB \\ Specific yield \\ Stress period \\ USDA \\ USGS \\ VBA \\ Actual evapotranspiration \\ The depth to and (or) elevation of the bottom of an aquifer. This bottom \\ may or may not be coincident with the stratigraphic bottom of a \\ formation. \\ The portion of streamflow derived from groundwater flow. \\ Base-flow index \\ Observation data that are used to match simulated output data from a \\ model. Examples of observation data can be water-level measurements \\ or base flow. \\ U.S. Geological Survey, Earth Resources Observation and Science Center \\ A macro written in Visual Basic to assign hydraulic properties to wells \\ based on lithologies \\ Geographic information system \\ A property of the aquifer that determines its ability to transmit water. \\ Inverse-distance weighted \\ A sequence of instructions that runs inside an application like Microsoft \\ Access. \\ Moderate Resolution Spectoradiometer \\ National Water Information System \\ Parameter-Elevation Regressions on Independent Slopes Model \\ SOil-WATer Balance Model \\ Simplified Surface Energy Balance Model \\ Soil Water Balance Model \\ The quantity of water that will drain from an aquifer by gravity. \\ A defined increment of time or time step that a model will be run in for \\ example yearly or monthly. \\ United States Department of Agriculture \\ United States Geological Survey \\ Visual Basic for Applications
}





\title{
Geodatabase Compilation of Hydrogeologic, Remote Sensing, and Water-Budget-Component Data for the High Plains Aquifer, 2011
}

\author{
By Natalie A. Houston, Sophia L. Gonzales-Bradford, Amanda T. Flynn, Sharon L. Qi, Steven M. Peterson, \\ Jennifer S. Stanton, Derek W. Ryter, Terry L. Sohl, and Gabriel B. Senay
}

\section{Abstract}

The High Plains aquifer underlies almost 112 million acres in the central United States. It is one of the largest aquifers in the Nation in terms of annual groundwater withdrawals and provides drinking water for 2.3 million people. The High Plains aquifer has gained national and international attention as a highly stressed groundwater supply primarily because it has been appreciably depleted in some areas. The U.S. Geological Survey has an active program to monitor the changes in groundwater levels for the High Plains aquifer and has documented substantial water-level changes since predevelopment: the High Plains Groundwater Availability Study is part of a series of regional groundwater availability studies conducted to evaluate the availability and sustainability of major aquifers across the Nation. The goals of the regional groundwater studies are to quantify current groundwater resources in an aquifer system, evaluate how these resources have changed over time, and provide tools to better understand a systems response to future demands and environmental stresses. The purpose of this report is to present selected data developed and synthesized for the High Plains aquifer as part of the High Plains Groundwater Availability Study. The High Plains Groundwater Availability Study includes the development of a water-budget-component analysis for the High Plains completed in 2011 and development of a groundwater-flow model for the northern High Plains aquifer. Both of these tasks require large amounts of data about the High Plains aquifer. Data pertaining to the High Plains aquifer were collected, synthesized, and then organized into digital data containers called geodatabases. There are 8 geodatabases, 1 file geodatabase and 7 personal geodatabases, that have been grouped in three categories: hydrogeologic data, remote sensing data, and water-budgetcomponent data. The hydrogeologic data pertaining to the northern High Plains aquifer is included in three separate geodatabases: (1) base data from a groundwater-flow model; (2) hydrogeology and hydraulic properties data; and (3) groundwater-flow model data to be used as calibration targets. The remote sensing data for this study were developed by the U. S. Geological Survey Earth Resources Observation and Science Center and include historical and predicted land-use/land-cover data and actual evapotranspiration data by using remotely sensed temperature data. The waterbudget-component data contains selected raster data from maps in the "Selected Approaches to Estimate Water-Budget Components of the High Plains, 1940 Through 1949 and 2000 Through 2009" report completed in 2011 (http://pubs.usgs. gov/sir/2011/5183/). Federal Geographic Data Committee compliant metadata were created for each spatial and tabular data layer in the geodatabases.

\section{Introduction}

The High Plains aquifer underlies almost 112 million acres in the central United States. The spatial extent of the High Plains aquifer includes parts of Colorado, Kansas, Nebraska, New Mexico, Oklahoma, South Dakota, Texas, and Wyoming (fig. 1). It is one of the largest aquifers in the Nation in terms of annual groundwater withdrawals and provides drinking water for 2.3 million people (McMahon and others, 2007). The aquifer also provides irrigation for almost one quarter of the total water needs for agricultural production in the Nation (Gurdak and others, 2007). In 2000, water withdrawals from the High Plains aquifer accounted for 21.2 percent of all groundwater withdrawn in the United States (Hutson and others, 2004). This amount of groundwater production makes the High Plains aquifer the most intensively pumped aquifer in the United States (Maupin and Barber, 2005). The High Plains aquifer has gained national and international attention as a highly stressed groundwater supply because in many areas it has been appreciably depleted (Gleeson and others, 2012). The continued decline in water levels, particularly in Kansas and Texas, has caused much concern about the sustainability of the aquifer and the associated agricultural production. 


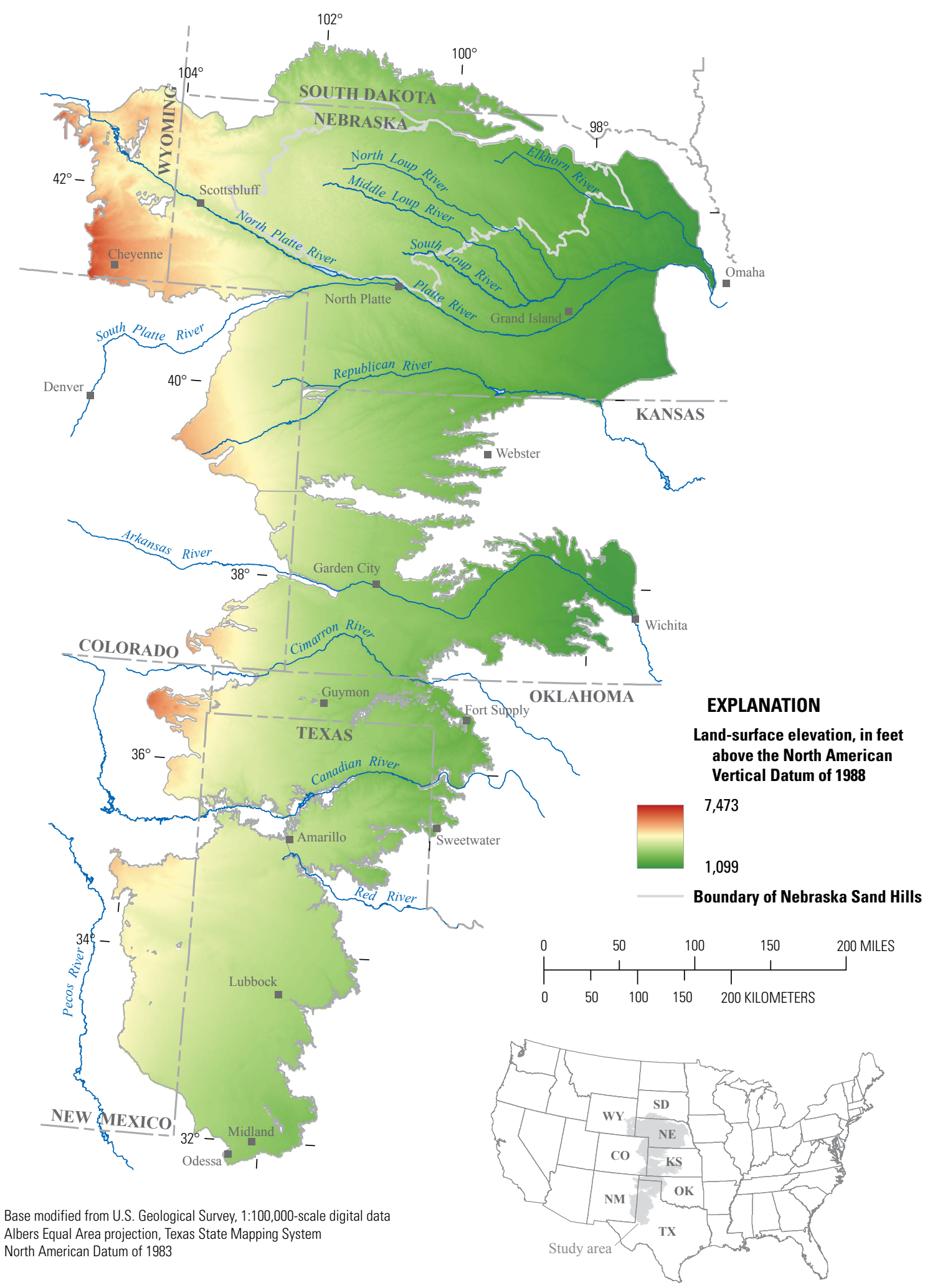

Figure 1. Location of the High Plains aquifer. 
The U.S. Geological Survey (USGS) has an active program to monitor the changes in groundwater levels for the High Plains aquifer (McGuire, 2011) and has documented substantial water-level changes since predevelopment: the High Plains Groundwater Availability Study is part of a series of regional groundwater availability studies conducted to evaluate the availability and sustainability of major aquifers across the Nation. The goals of the regional groundwater studies are to quantify current groundwater resources in an aquifer system, evaluate how these resources have changed over time, and provide tools to better understand a systems response to future demands and environmental stresses. The High Plains Groundwater Availability Study started in 2009.

The High Plains aquifer is regionally divided into the northern High Plains, the central High Plains, and the southern High Plains aquifers (fig. 2). During phase 1 of a two-phase study, a water-budget-component analysis was completed for the entire High Plains aquifer to gain a better understanding of the components of the water budget that control the flow system of the aquifer (Stanton and others, 2011). Unlike the central High Plains and southern High Plains aquifers, a comprehensive study and groundwater-flow model had not been completed for the entire northern High Plains aquifer since 1988.

Since 2001, a number of hydrogeologic framework studies and groundwater-flow models for the central and southern High Plains aquifers have been published through the Texas Water Development Board's Groundwater Availability Model (GAM) program. A groundwater-flow model for the southern High Plains aquifer was completed in 2003 (Blandford and others, 2003) and then updated in 2008 to include the underlying Edwards-Trinity High Plains aquifer (Blandford and others, 2008). A groundwater-flow model was completed for the central High Plains aquifer in 2001 (Dutton and others, 2001) and then updated in 2010 to include a refined base of the aquifer along with updated groundwater withdrawal information (Kelly and others, 2010); therefore, also during phase 1 of this study, the USGS compiled hydrogeologic and hydraulic data pertaining to the northern High Plains aquifer. Data documented for the northern High Plains aquifer in this report for phase 1 will be used to support the future development of a comprehensive hydrogeologic framework and groundwater-flow model during phase 2 of the study to complete the data-collection effort for the High Plains aquifer system.

The data that were collected and synthesized for the water-budget-component analysis and the northern High Plains groundwater-flow model were organized into digital data containers called "geodatabases." A geodatabase is a database that allows users to associate tabular data with physical and spatial components (Shah and Houston, 2007). Geodatabases are capable of handling volumes of data efficiently through the use of a relational database management system. The contents of a geodatabase can be explored interactively by using a geographic information system (GIS). Although phase 2 of the study will also include a data compilation component, some of the data documented in this report for phase 1 will form the basis for the hydrologic framework and groundwater modeling work that will be done in phase 2 .

\section{Purpose and Scope}

The purpose of this report is to document the data collected, synthesized, and evaluated for the High Plains aquifer as part of the High Plains Groundwater Availability Study. Digital and nondigital data were gathered from existing databases, State agencies, and previously published models and reports and then organized by theme. Remote sensing data for historical and predicted land-use/land-cover (LULC) and actual evapotranspiration data developed for the High Plains are also included in this report. The geodatabase compilation methods include an explanation of the geodatabase design, data integration steps, and quality assurance controls. The metadata for each of the datasets in the geodatabases are briefly described and are available with the online version of this report.

\section{Description of Study Area}

The study area for this report includes all three regions of the High Plains aquifer. The three regions (northern High Plains, central High Plains, and southern High Plains) were defined in previous studies by using natural aquifer boundaries, air-temperature gradients, and logistical considerations associated with water-quality sample collection (Weeks and others, 1988; McMahon and others, 2007; Stanton and others, 2011). The northern High Plains aquifer underlies parts of Colorado, Kansas, Nebraska, South Dakota, and Wyoming. McMahon and others (2007) provided a detailed description of the hydrogeology and climate of the northern High Plains aquifer in Nebraska. The central High Plains underlies parts of Colorado, Kansas, New Mexico, Oklahoma, and Texas. Luckey and Becker (1999) described the hydrology of the central High Plains aquifer. The southern High Plains aquifer underlies eastern New Mexico and northwestern Texas. Blanford and others (2003) described the hydrogelogic setting of the southern High Plains aquifer.

\section{Geodatabase Compilation Methods}

The High Plains Groundwater Availability Study includes development of a water-budget-component analysis completed in 2011 for the High Plains (Stanton and others, 2011) and the development of a groundwater-flow model for the northern High Plains aquifer in progress (2013). Both of these tasks require large amounts of data about the High Plains aquifer. Initial steps included obtaining detailed information on the 


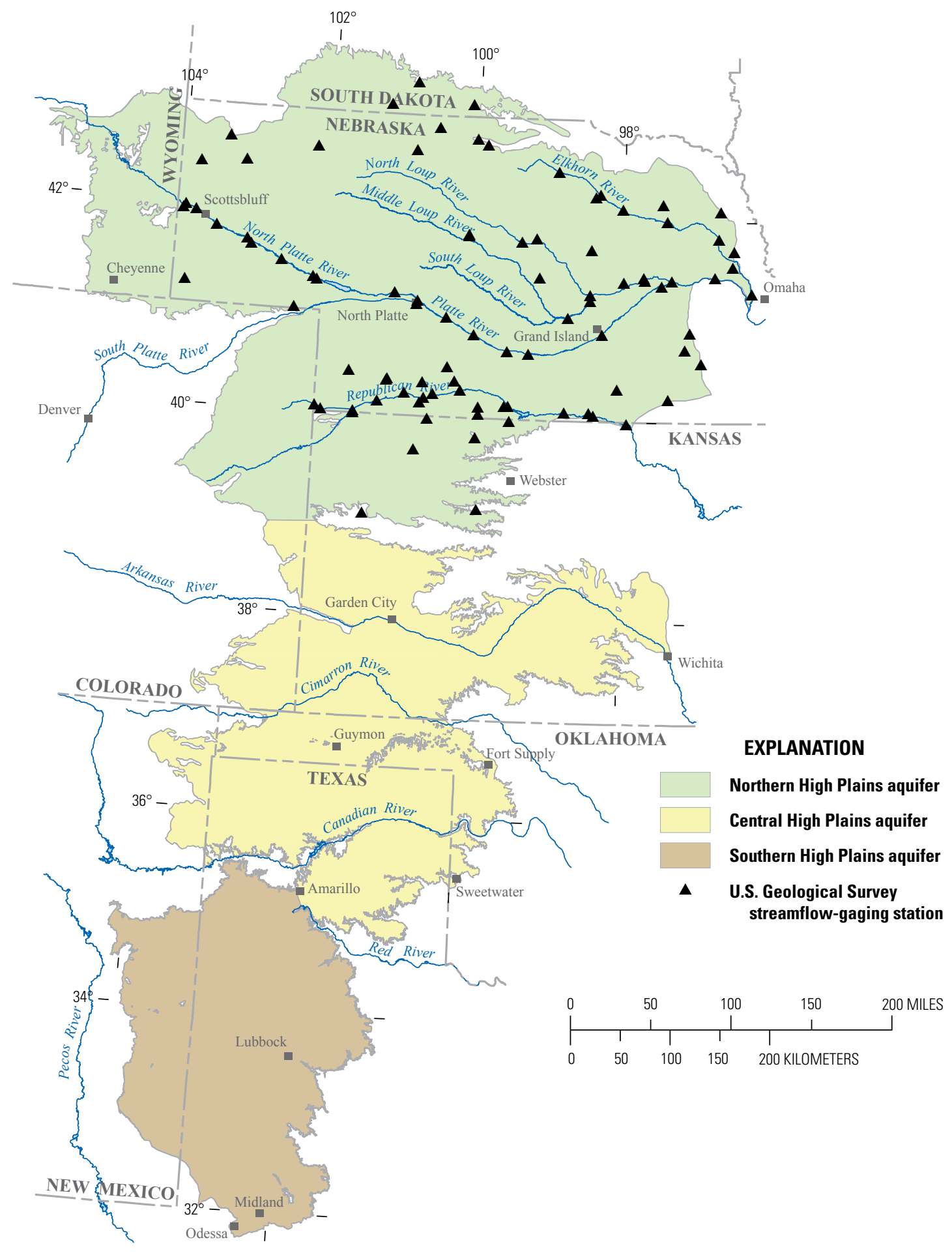

Base modified from U.S. Geological Survey, 1:100,000-scale digital data Albers Equal Area projection, Texas State Mapping System North American Datum of 1983

Figure 2. Location of the High Plains aquifer, which is regionally divided into the northern High Plains, central High Plains, and southern High Plains aquifers. 
structure and hydraulic properties of the hydrogeologic units and preparing the data for use in the various models. Also required were data documenting how the landscape above the aquifer has changed over time and how those changes may have affected water levels. Two types of geodatabases were used in this study, a personal geodatabase and a file geodatabase. A personal geodatabase can be managed in the Environmental Systems Research Institute (ESRI) suite of products or in Microsoft Access through traditional database queries. The personal geodatabase has a size limitation of 2 gigabytes of data. A file geodatabase is designed to manage larger datasets but can only be managed in ESRI software. The file geodatabase has a size limitation of 2 terabytes (Environmental Systems Research Institute, 2011). With either type of geodatabase, a GIS can be used to view the spatial data in combination with other relevant geospatial data layers (for example: aerial imagery, surface geology, administrative boundaries) to analyze distribution patterns, data gaps, and spatial relationships and to create cartographic representations of the geodatabase contents.

\section{Geodatabase Design}

Project data were organized into thematic geodatabases by subject matter (hydrogeologic data, predicted LULC, historical LULC, and so forth) for ease of management and distribution. The projection for feature classes (spatial layers of data representing the various types of vector geometry such as point, line, and polygons) and rasters (rows and columns of gridded information, where each cell in the grid contains a value representing unique information) in all geodatabases for this study was Albers Equal-Area Conic coordinate system, North American Datum 1983. For the study area, 8 geodatabases, 1 file geodatabase, and 7 personal geodatabases were developed.

\section{Data Integration}

The following sections will provide more information on the eight geodatabases discussed in the previous section. The data have been grouped into three categories by data type: hydrogeologic data, remote sensing data, and water-budgetcomponent data.

\section{Hydrogeologic Data}

Hydrogeologic data for the northern High Plains aquifer are included in three separate geodatabases for this report: one for base data from the northern High Plains groundwater-flow model, a second for the northern High Plains hydrogeology and hydraulic properties data, and a third for the northern High Plains groundwater-flow model data to be used as calibration targets (table 1). Calibration targets are included as the observed or measured data that will be used to match simulated data in the northern High Plains groundwater-flow model in progress (2013).

The geodatabase of base data from the northern High Plains groundwater-flow model is a personal geodatabase containing two feature datasets: model-boundary and stream-elevations. The model-boundary feature dataset contains the northern High Plains groundwater-flow-model grid as both a cell (ply_NHP_ModelCells) and a centroid (pts_NHP_ModelCellCentroid) feature class. The modelboundary-feature dataset also contains a feature class (ply NHP_ModelBoundary) that depicts the active and inactive areas of the northern High Plains groundwater-flow model. The stream-elevations-feature dataset contains the stream elevations that were extracted from the 1:100,000 National Hydrography Dataset (NHD) Plus, edition 2.10, stream segments (U.S. Environmental Protection Agency, 2012) that flow through the northern High Plains model cells. Streams were initially included if they had a mean estimated base flow of more than 10 cubic feet per second (based on streamflow data from long-term streamflow-gaging stations operated by the USGS (U.S. Geological Survey, 2012) or the Nebraska Department of Natural Resources (Nebraska Department of Natural Resources, 2012). The stream network then was expanded to include selected streams that were deemed hydrogeologically important but had a mean estimated base flow of less than 10 cubic feet per second.

The northern High Plains hydrogeology and hydraulic properties geodatabase is a personal geodatabase that contains the base of the northern High Plains aquifer lithologic tabular and spatial data and hydraulic properties tabular and spatial data. The lithologic data representing the base of the aquifer were compiled from various sources and different formats and incorporated into a geodatabase as tabular data. Data were compiled from lithologic logs (hereinafter, "logs") made by drillers during the installation of wells or drilling of boreholes and obtained from various Federal and State agencies or from published reports. By using the description of lithology for each interval, the depth to the base of the northern High Plains aquifer was identified at each well or borehole. Data were also obtained from completed groundwater-flow models including the Upper Big Blue (UBB) (Bitner, 2005), the Cooperative Hydrology Study (COHYST) (Cannia and others, 2006), and the ElkhornLoup (ELM) (Stanton and others, 2010). The spatial dataset titled "The Enhanced Bedrock Elevations Estimates for the Ogallala Aquifer in Kansas," (OgallalaBDE) developed by the Kansas Geological Survey in 2005 (Kansas Geological Survey, 2005) was also used in this study to refine the base of the northern High Plains aquifer. The resulting data were converted to a feature class of well and borehole data called "pts_Depth2Bedrock," which represents the base of the northern High Plains aquifer. 
Table 1. Description and definition of data compiled and entered into the geodatabases, which are a compilation of hydrogeologic, remote sensing, and water-budgetcomponent data for the High Plains aquifer, 2011.

\begin{tabular}{|c|c|c|c|c|c|}
\hline $\begin{array}{l}\text { Data series } \\
\text { report grouping }\end{array}$ & Geodatabase name & $\begin{array}{l}\text { Feature dataset/ } \\
\text { theme }\end{array}$ & $\begin{array}{l}\text { Feature class/table name/ } \\
\text { climate scenario }\end{array}$ & $\begin{array}{l}\text { Data } \\
\text { type }\end{array}$ & Description \\
\hline \multirow[t]{4}{*}{ Hydrogeologic } & $\begin{array}{l}\text { DS777_northern_High_Plains } \\
\text { groundwater_flow_model_base_ } \\
\text { data.mdb }\end{array}$ & model_boundary & ply_NHP_ModelCells & polygon & $\begin{array}{l}\text { Spatial location of northern High Plains groundwater-flow } \\
\text { model cell boundaries. }\end{array}$ \\
\hline & & & ply_NHP_ModelBoundary & polygon & $\begin{array}{l}\text { Spatial location of the exterior boundary that includes } \\
\text { active and inactive areas of the northern High Plains } \\
\text { groundwater-flow model. }\end{array}$ \\
\hline & & & pts_NHP_ModelCellCentroid & point & $\begin{array}{l}\text { Spatial location of northern High Plains groundwater-flow } \\
\text { model cell centroids. }\end{array}$ \\
\hline & & stream_elevations & pts_StreamElevations & point & $\begin{array}{l}\text { Spatial location of stream elevations used in the Modflow } \\
\text { streamflow-routing package. }\end{array}$ \\
\hline \multirow[t]{6}{*}{ Hydrogeologic } & $\begin{array}{l}\text { DS777_northern_High_Plains } \\
\text { hydrogeologic_and_hydraulic_ } \\
\text { properties.mdb }\end{array}$ & Base of aquifer & pts_Depth2Bedrock & point & $\begin{array}{l}\text { Spatial locations of wells with elevations of the base of the } \\
\text { High Plains aquifer. }\end{array}$ \\
\hline & & & tbl_LithologyAggregate & table & $\begin{array}{l}\text { Nonspatial lithology information synthesized from } \\
\text { drillers' logs, previous groundwater-flow models, and } \\
\text { publications. }\end{array}$ \\
\hline & & $\begin{array}{l}\text { Hydraulic } \\
\text { properties }\end{array}$ & pts_K_Sy_TWA & point & $\begin{array}{l}\text { Spatial location of wells with computed hydraulic } \\
\text { conductivity and specific yield values. }\end{array}$ \\
\hline & & & tbl_K_Sy_RawDataMaster & table & $\begin{array}{l}\text { Nonspatial lithology information use to derive hydraulic } \\
\text { conductivy and specific yield by interval. }\end{array}$ \\
\hline & & & tbl_Material & table & $\begin{array}{l}\text { Nonspatial texture information used to compute hydraulic } \\
\text { conductivity and specific yield. }\end{array}$ \\
\hline & & & tbl_Multiplier & table & $\begin{array}{l}\text { Nonspatial additional texture information used to adjust } \\
\text { computations of hydraulic conductivity and specific yield. }\end{array}$ \\
\hline \multirow[t]{4}{*}{ Hydrogeologic } & $\begin{array}{l}\text { DS777_northern_High_Plains_ } \\
\text { groundwater_flow_model_ } \\
\text { calibration_targets.mdb }\end{array}$ & Predevelopment & pts_BaseFlow_predevelopment & point & $\begin{array}{l}\text { Spatial location of gages with total flow and estimated base } \\
\text { flow, for the predevelopment simulation period. }\end{array}$ \\
\hline & & & pts_WaterLevel_predevelopment & point & $\begin{array}{l}\text { Spatial locations of wells with water-level measurements } \\
\text { for the first occurrence of a water-level measurement } \\
\text { recorded at a well. }\end{array}$ \\
\hline & & Development & pts_BaseFlow_development & point & $\begin{array}{l}\text { Spatial location of gages with total flow and estimated } \\
\text { base flow, organized by seasonal stress period for the } \\
\text { development model period. }\end{array}$ \\
\hline & & & pts_WaterLevel_development & point & $\begin{array}{l}\text { Spatial location of wells with water-level measurements } \\
\text { taken in the spring and fall from September } 1940 \text { to } \\
\text { April } 2009 .\end{array}$ \\
\hline Remote sensing & $\begin{array}{l}\text { DS777_High_Plains_historical_land_ } \\
\text { use.gdb }\end{array}$ & Historical land use & & raster & $\begin{array}{l}\text { Annual model-backcasted land use/land cover rasters from } \\
1949 \text { to } 2008 \text {. }\end{array}$ \\
\hline \multirow[t]{2}{*}{ Remote sensing } & $\begin{array}{l}\text { DS777_High_Plains_predicted_land_ } \\
\text { use_a2.mdb }\end{array}$ & Predicted land use & IPCC climate scenario A2 & raster & $\begin{array}{l}\text { Annual model-forecasted land use/land cover rasters from } \\
2009 \text { to } 2050 \text { for the A2 climate scenario. }\end{array}$ \\
\hline & $\begin{array}{l}\text { DS777_High_Plains_predicted_land_ } \\
\text { use_b2.mdb }\end{array}$ & Predicted land use & IPCC climate scenario B2 & raster & $\begin{array}{l}\text { Annual model-forecasted land use/land cover rasters from } \\
2009 \text { to } 2050 \text { for the B2 climate scenario. }\end{array}$ \\
\hline
\end{tabular}


Table 1. Description and definition of data compiled and entered into the geodatabases, which are a compilation of hydrogeologic, remote sensing, and water-budgetcomponent data for the High Plains aquifer, 2011.-Continued

\begin{tabular}{|c|c|c|c|c|c|}
\hline $\begin{array}{l}\text { Data series } \\
\text { report grouping }\end{array}$ & Geodatabase name & $\begin{array}{c}\text { Feature dataset/ } \\
\text { theme }\end{array}$ & $\begin{array}{l}\text { Feature class/table name/ } \\
\text { climate scenario }\end{array}$ & $\begin{array}{l}\text { Data } \\
\text { type }\end{array}$ & Description \\
\hline Remote sensing & $\begin{array}{l}\text { DS777_High_Plains_actual_ } \\
\text { evapotranspiration.mdb }\end{array}$ & Evapotranspiration & & raster & $\begin{array}{l}\text { Monthly actual evapotranspiration rasters calculated using } \\
\text { the Simplified-Surface-Energy-Balance (SSEB) model } \\
\text { from April } 2000 \text { to December 2009. Used as an input } \\
\text { variable for the SOil WATer Balance (SOWAT) model. }\end{array}$ \\
\hline \multirow[t]{15}{*}{$\begin{array}{l}\text { Water-budget } \\
\text { components }\end{array}$} & $\begin{array}{l}\text { DS777_High_Plains_water_budget_ } \\
\text { components.mdb }\end{array}$ & Precipitation & PRISM_PRECIP_AVEIN_4049 & raster & $\begin{array}{l}\text { Average annual precipitation data in inches, } 1940-49 \text {, } \\
\text { estimated from the Parameter-Elevation Regressions on } \\
\text { Independent Slopes Model (PRISM). }\end{array}$ \\
\hline & & & PRISM_PRECIP_AVEIN_0009 & raster & $\begin{array}{l}\text { Average annual precipitation data in inches, } 2000-9 \text {, } \\
\text { estimated from the Parameter-Elevation Regressions on } \\
\text { Independent Slopes Model (PRISM). }\end{array}$ \\
\hline & & & NWS_PRECIP_AVEIN_0009 & raster & $\begin{array}{l}\text { Average annual precipitation data in inches, } 2000-9 \text { from } \\
\text { the National Weather Service (NWS) Snow accumulation } \\
\text { and ablation model (SNOW-17). }\end{array}$ \\
\hline & & & IDW_PRECIP_AVEIN_4049 & raster & $\begin{array}{l}\text { Average annual precipitation data in inches } 1940-49 \text {, } \\
\text { estimated from Inverse-Distance-Weighted (IDW) } \\
\text { interpolation. }\end{array}$ \\
\hline & & & IDW_PRECIP_AVEIN_0009 & raster & $\begin{array}{l}\text { Average annual precipitation data in inches, } 2000-9 \text {, } \\
\text { estimated from the Inverse-Distance-Weighted (IDW) } \\
\text { interpolation. }\end{array}$ \\
\hline & & Evapotranspiration & NWS_PET_AVEIN_0009 & raster & $\begin{array}{l}\text { Average annual potential evapotranspiration } 2000-9 \text {, in } \\
\text { inches estimated from estimated from the National } \\
\text { Weather Service (NWS) Snow accumulation and ablation } \\
\text { model (SNOW-17). }\end{array}$ \\
\hline & & & NWS_AET_AVEIN_0009 & raster & $\begin{array}{l}\text { Average annual actual evapotranspiration in inches 2000-9, } \\
\text { estimated from the National Weather Service (NWS) } \\
\text { Snow accumulation and ablation model (SNOW-17). }\end{array}$ \\
\hline & & & SSEB_AET_AVEIN_0009 & raster & $\begin{array}{l}\text { Average annual actual evapotranspiration in inches, } 2000-9 \text {, } \\
\text { estimated from the Simplified-Surface-Energy-Balance } \\
\text { (SSEB) model. }\end{array}$ \\
\hline & & & SWB_AET_AVEIN_4049 & raster & $\begin{array}{l}\text { Average annual actual evapotranspiration in inches } 1940- \\
49 \text {, estimated from the Soil Water Balance model (SWB). }\end{array}$ \\
\hline & & & SWB_AET_AVEIN_0009 & raster & $\begin{array}{l}\text { Average annual actual evapotranspiration in inches } 2000- \\
09 \text {, estimated from the Soil Water Balance model (SWB). }\end{array}$ \\
\hline & & Recharge & SWB_RCH_AVEIN_4049 & raster & $\begin{array}{l}\text { Average annual recharge in inches } 1940-49 \text {, estimated from } \\
\text { the Soil Water Balance model (SWB). }\end{array}$ \\
\hline & & & SWB_RCH_AVEIN_0009 & raster & $\begin{array}{l}\text { Average annual recharge in inches } 2000-9 \text {, estimated from } \\
\text { the Soil Water Balance model (SWB). }\end{array}$ \\
\hline & & & SOWAT_RCH_AVEIN_0009 & raster & $\begin{array}{l}\text { Average annual recharge in inches } 2000-9 \text {, estimated from } \\
\text { the SOil WATer Balance Model (SOWAT). }\end{array}$ \\
\hline & & Irrigation & SWB_IRR_AVEIN_0009 & raster & $\begin{array}{l}\text { Average annual irrigation withdrawals in inches } 2000-9 \text {, } \\
\text { estimated from the Soil Water Balance model (SWB). }\end{array}$ \\
\hline & & & SOWAT_IRR_AVEIN_0009 & raster & $\begin{array}{l}\text { Average annual irrigation withdrawals in inches } 2000-9 \text {, } \\
\text { estimated from the SOil WATer Balance model (SOWAT). }\end{array}$ \\
\hline
\end{tabular}


The geodatabase also contains a feature class of the thickness-weighted average (TWA) hydraulic conductivity (k) and specific yield (Sy) values called "pts_K_Sy_TWA," and a table called "tbl_K_Sy_RawDataMaster" containing the parts of logs used to determine these values, a macro called "Geoparm", and tables called "tbl_Material" and "tbl_Multiplier" that were used to assign the values in the tbl_K_Sy_RawDataMaster for each interval in a log. By using the Geoparm macro, $\mathrm{k}$ values in feet per day were automatically assigned to the lithology represented at a given well on the basis of drill cutting description of the lithology obtained from logs. Richard Kern developed the original program called "Geoparm" that was used in the COHYST model. Kern used lithologic descriptions provided in a table developed by E.C. Reed and R. Piskin at the University of Nebraska Conservation and Survey Division School of Natural Resources (Cannia and others, 2006). Kern modified the Reed and Piskin table to fit the particular lithologies he encountered for the COHYST model. Kern's program read the original logs into the Geoparm program assigning values for $\mathrm{k}$ and Sy as each log was read.

The Geoparm program documented in Cannia and others (2006) was modified slightly for this report. Rather than reading the logs into a program, the contents of the logs were entered into a database table and a macro written in Visual Basic for Applications (VBA) to read the values of the attributes in the table (geologic material, texture, and grain size) for each section of the log. A macro is a sequence of instructions that runs inside an application like Microsoft Access to automate tasks without programming (Groh and others, 2007; Walkenbach, 2007). Next, the macro queried the tables to assign or compute the values of $\mathrm{k}$ and Sy for each section of the log. The table tbl_Material contains all of the geologic materials found in this study along with the $\mathrm{k}$ and Sy values assigned to those materials determined by how well they are sorted based on grain size. This table was obtained from Kern's table (Cannia and others, 2006) and modified to include any additional geologic materials in this study. The table tbl_Multiplier contains any additional modifying characteristics of a material that would reduce the assigned value of $\mathrm{k}$; for example a descriptor of silty would multiply the value for $\mathrm{k}$ by 0.5 (Cannia and others, 2006). The northern High Plains groundwater-flow model calibration targets is a personal geodatabase that contains two feature classes for base flow and two for water levels - predevelopment and development base flow, (pts_BaseFlow_predevelopment and pts_BaseFlow_development), and predevelopment and development water levels (pts_WaterLevel_development and pts_WaterLevel_predevelopment). The base-flow feature classes were developed by using daily streamflow data collected from 91 streamflow-gaging stations for the development base-flow data and 25 streamflow-gaging stations for the predevelopment base-flow data across the extent of the northern High Plains aquifer (fig. 2). Streamflow-gaging data were obtained from the USGS National Water Information System (NWIS) (U.S. Geological Survey, 2012) or the Nebraska Department of Natural Resources Stream Gaging
Data Bank (Nebraska Department of Natural Resources, 2012). The data from each site were processed by using "A Computer Program for Determining an Index to Base Flow (BFI)," version 4.15 (Wahl and Wahl, 2007) to determine the base-flow component of streamflow at each site. The two water-level feature classes were developed by using data from NWIS (U.S. Geological Survey, 2012), and the High Plains Water-Level Monitoring Network data developed and maintained by the USGS. The predevelopment simulation water-level data have water-level measurements recorded from 1930 to 1980 . The development simulation of water-level data contains water-level measurements recorded from 1940 through 2009. Data were separated by date into 138 irrigation and nonirrigation periods called "stress periods." These target data will be used to calibrate the northern High Plains groundwater-flow model in development (2013).

\section{Remote Sensing Data}

Remote sensing datasets were developed by the USGS Earth Resources Observation and Science (EROS) Center. The data are historical (backcasted) LULC data from 1949 through 2008, predicted (forecasted) LULC data from 2009 through 2050, and actual evapotranspiration from 2000 through 2009. The historical LULC data are 250-meter resolution rasters generated annually for the entire High Plains aquifer by using the FOREcasting SCEnarios (FORE-SCE) of future land-cover model (Sohl and others, 2007; Sohl and Sayler, 2008). Data from the U.S. Census of Agricultural (Gutmann, 2005a), U.S. Census (Gutmann, 2005b), and the USGS's Land Cover Trends project (Loveland and others, 2002) were used to create the historical land-cover patterns. The predictive LULC data are 250-meter rasters that were also generated by using the FORE-SCE model (Sohl and others, 2007; Sohl and Sayler, 2008). Predicted LULC data parsed by ecoregion were developed annually by using characteristics and assumptions consistent with the Intergovernmental Panel on Climate Change scenarios (IPCC) Special Report on Emissions Scenarios (SRES) storylines A2 and B2 (Nakicenovic and others, 2000) and historical data from the USGS's Land Cover Trends Project (Loveland and others, 2002). The IPCC developed four alternate scenarios (A1, A2, B1, and B2) representing different futures with respect to population growth, economic growth, and the use of fossil fuels. A2 is an economically oriented scenario characterized by loss of natural land covers and expansion of agricultural and urban land uses, and B2 is an environmentally oriented scenario characterized by declines in agriculture and slight increases in natural land covers. Both A2 and $\mathrm{B} 2$ assume regional approaches to economic growth and environmental issues, whereas A1-which is also an economically oriented scenario - and B1-which is also an environmentally oriented scenario - assume a global approach. Spatial modeling of the two regional scenarios provided spatial patterns of land-use change consistent with underlying assumptions and processes associated with each scenario. 
The LULC data were based on The U.S. Department of Agriculture's (USDA) 2008 Cropland Data Layer (CDL) (U.S. Department of Agriculture National Agricultural Statistics Service, 2008). Both the historical and predicted LULC data were combined into 18 classes: corn, cotton, sorghum, soybeans, wheat/small grains, alfalfa/hay, other crops, fallow, open water, developed, barren, deciduous forest, mixed forest, evergreen forest, shrubland, grassland, woody wetland, and herbaceous wetland.

The actual evapotranspiration (AET) data are 1,000meter resolution rasters generated monthly from March 2000 to December 2009 and developed by using the SimplifiedSurface-Energy-Balance (SSEB) model. The SSEB model estimates evapotranspiration in millimeters by using remotely sensed temperature data obtained from the Moderate Resolution Imaging Spectoradiometer (MODIS) sensors (Senay and others, 2007). These rasters were used in the SOil WATer Balance model (SOWAT) (Kahle and others, 2011) to develop estimates of irrigation and recharge.

\section{Water-Budget-Component Data}

The water-budget-component geodatabase is a personal geodatabase that contains selected raster data from maps in the "Selected Approaches to Estimate Water-Budget Components of the High Plains, 1940 through 1949 and 2000 through 2009" report (hereinafter referred to as the "WaterBudget-Component Report") (Stanton and others, 2011). The Water-Budget-Component Report focused on the use of new methods to estimate various components of a water budget and then compared those estimates to existing studies. Data were collected and synthesized from existing climate models including the Parameter-Elevation Regressions on Independent Slopes Model (PRISM) (Daly and others, 1994), Snow accumulation and ablation model (SNOW-17) (Anderson, 2006), and the SSEB model (Senay and others, 2007) and used both in and out of soil-water-balance models to compute various components of a water budget. Data for four components of the water budget are presented (precipitation, evapotranspiration, irrigation, and recharge) in 15 rasters. The methodologies used to compute the averages and volumes for the data in this geodatabase are slightly different depending on how the datasets were used. The methods used to compute the average annual rates for recharge, actual and potential evapotranspiration, irrigation, and precipitation for the 1940 49 and 2000-9 time periods and the volumes are discussed briefly and further documented in the metadata for each of the rasters.

The Soil Water Balance (SWB) model (Westenbroek and others, 2010) developed primarily to simulate recharge was used to compute recharge, and actual evapotranspiration in inches for the 1940-49 and 2000-9 time periods, and irrigation in inches for 2000-9 time period. For all rasters output by the SWB model, active raster cells were converted to points and then spatially joined to the areal polygons representing the State and regional polygons (fig. 2). Next, all of the points that fell inside the boundary of the High Plains were summarized to get an average rate in inches per year for each High Plains aquifer region (northern, central, and southern) and each State area within the High Plains boundary. For the Water-Budget-Component Report (Stanton and others, 2011) average rates were then multiplied by the areal extent to get the volume in acre-feet. There are 195,673 active cells in the native rasters produced by SWB, all originally in State Plane feet, Federal Information Processing Standard (FIPS) 2600 projection.

For SOWAT, data are output in millimeters as monthly layers for multiple water-budget components that include computations of irrigation applications and recharge and then converted to inches for the time period 2000-9. The irrigation and recharge data for SOWAT were then summarized annually by region and State by using a zone-budget routine within the SOWAT software package. Two zone layers were created by making zone masks representing the High Plains aquifer regions and the State areas within the High Plains boundary (fig. 2). The zone layers included the areas of NODATA where the aquifer is not present within the boundary of the High Plains aquifer. Volume data then were computed outside of SOWAT by using the irrigation applications rates, recharge, and the area in acres of the various zones representing the High Plains aquifer regions and State areas.

For the SSEB, model data are output in millimeters as monthly layers for the water-budget components AET. The average AET rates converted to inches for the 118 months beginning in March 2000 and ending in December 2009 for each of the various zones were obtained by using the zonal statistics tool in ArcGIS 9.3.1 (Environmental Systems Research Institute, 2011).

The average annual rates for all of the precipitation data as well as the SNOW-17 model data (PRISM, NWS, and IDW rasters) also were computed by using zonal statistics in ArcGIS 9.3.1(Environmental Systems Research Institute, 2011). Volume data were computed by multiplying the rate in inches by the area in acres of the various zones.

\section{Quality Assurance}

Efforts were made to identify and eliminate duplicate data between sources where possible. Duplicate information may exist in the Ogallala BDE data that could not be identified because the researchers that developed the Ogallala BDE did not maintain a link in their feature class to the original source material. Additionally, spatial coordinates for the wells in the Ogallala BDE were computed by using a program developed by the Kansas Geological Survey. The program uses the legal description reported for the well and then locates the well to the center of the smallest description of a parcel of land (such as township, range, and section) provided by an agency (Brownie Wilson, oral commun. 2010). Wells that appear to be spatially coincident may for example be located only to the nearest section (1 mile by 1 mile). 
The Cooperative Hydrology Study test-hole database (COHYST TH DB) and the Nebraska Conservation and Survey Division test-hole database (NE CSD TH DB) sources contained overlap in their study areas. Duplicate wells or boreholes were difficult to identify because researchers who developed the COHYST groundwater-flow model renamed the NE CSD TH DB wells or boreholes by removing special characters in the well or borehole name and adding a numeric suffix (for example, the NE CSD TH DB well or borehole identifier 47-b-53 became 47b53.062 in the COHYST TH $\mathrm{DB})$, If the site information from the COHYST groundwaterflow-model database was retained, when and where possible the actual well or borehole identifier assigned in the NE CSD TH DB was retained and recorded in a field called Alt_Well_Id.

For the test-hole data for the UBB groundwaterflow model, researchers used the registration number as the unique identifier for the well or borehole. The well or borehole identifier assigned by the Nebraska Department of Natural Resources can be obtained by going to the registered groundwater wells data retrieval Web site at http://dnrdata.dnr. ne.gov/wellscs.

Additionally, tabular information can be reviewed postquery by using a combination of key fields, such as well identifier or source agency to help identify potential duplicates. Although these steps can help to further eliminate duplicate data, duplicate data may still exist in the postquery results because naming conventions and data-handling errors are inherited from each database.

\section{Metadata}

Federal Geographic Data Committee (FGDC) compliant metadata were created for each spatial and tabular data layer in the geodatabases. Metadata are descriptive information about a spatial data layer or table and typically include how the spatial data layer or table was created, its geographic setting, and its projected coordinate system. Other metadata components include title, abstract, publication date, and sourcing information. The metadata also describe the fields in the layer, called attributes, and their potential range of values, or domain. A detailed listing of the standard metadata contents can be found at http://www.fgdc.gov/metadata (Federal Geographic Data Committee, 2012).

\section{Cited References}

Anderson, Eric, 2006, Snow accumulation and ablation model-SNOW-17: National Weather Service River Forecast System user's manual, 44 p., accessed May 14, 2013, at http://www.nws.noaa.gov/oh/hrl/nwsrfs/users _ manual/part2/_pdf/22snow17.pdf.
Bitner, R.J., 2005, A groundwater model to determine the area within the Upper Big Blue Natural Resources District where groundwater pumping has the potential to increase flow from the Platte River to the underlying aquifer by at least 10 percent of the volume pumped over a 50 year period: Upper Big Blue Natural Resources District, 24 p., accessed May 14, 2013 at, http://nlc1.nlc.state.ne.us/epubs/N1500/B0072005.pdf.

Blandford, T.N., Blazer, D.J., Calhoun, K.C., Dutton, A.R., Naing, Thet, Reedy, R.C., and Scanlon, B.R., 2003, Groundwater availability of the southern Ogallala aquifer in Texas and New Mexico-Numerical simulations through 2050: Final report prepared for the Texas Water Development Board by Daniel B. Stephens and Associates Inc., 158 p., accessed May 14, 2013, at http://www.twdb. state.tx.us/groundwater/models/gam/ogll_s/OGLL_S_Full_ Report.pdf.

Blandford T.N., Kuchanur, Muthu, Standen, A.R., Ruggiero, Robert, Calhoun K.C., Kirby, Paul, and Shah, Gopika, 2008, Groundwater availability model of the Edwards-Trinity (High Plains) aquifer in Texas and New Mexico: Final report prepared for the Texas Water Development Board by Daniel B. Stephens and Associates, Inc., 176 p., accessed May 14, 2013, at http://www.twdb.state.tx.us/groundwater/ models/gam/ethp/ETHP_Model_Report.pdf.

Cannia, J.C., Woodward, D.W., and Cast, L.D., 2006, Cooperative Hydrology Study hydrostratigraphic units and aquifer characterization report: Cooperative Hydrology Study, 91 p., accessed May 14, 2013, at http://cohyst.dnr. ne.gov/document/dc012hydro_aquifer_022406.pdf.

Daly, Christopher, Neilson, R.P., and Phillips, D.L., 1994, A statistical-topographic model for mapping climatological precipitation over mountainous terrain: Journal of Applied Meteorology, v. 33, no. 2, p. 140-158.

Dutton, A.R., Reedy, R.C., and Mace, R.E., 2001, Saturated thickness in the Ogallala aquifer in the Panhandle water planning area — Simulation of 2000 through 2050 withdrawal projections: Austin, Texas Water Development Board, 39 p., accessed August 25, 2010, at https://www. twdb.texas.gov/groundwater/models/gam/ogll_n/OGLL_N_ Model_Report.pdf.

Environmental Systems Research Institute, 2011, ArcGIS-A complete integrated system: accessed January 31, 2011, at http://www.esri.com/software/arcgis/index.html.

Federal Geographic Data Committee, 2012, Geospatial metadata standards: Federal Geographic Data Committee, accessed May 14, 2013, at http://www.fgdc.gov/metadata/ geospatial-metadata-standards. 
Gleeson, Tom, Yoshihide, Wada, Marc, F.P., Bierkens, Ludovicus, van Beek, P.H., 2012, Water balance of global aquifers revealed by groundwater footprint: Nature, v. 488, no. 7410, p. 197-200, accessed May 14, 2013, 2013, at http://www.nature.com/nature/journal/v488/n7410/full/ nature11295.html.

Groh, M.R., Stockman, J.C., Powell, Gavin, Prague, C.N., Irwin, M.R., and Reardon, Jennifer, 2007, Access 2007 bible: Indianapolis, Wiley, 1,356 p.

Gurdak, J.J., Hanson, R.T., McMahon, P.B., Bruce, B.W., McCray, J.E., Thyne, G.D., and Reedy, R.C., 2007, Climate variability controls on unsaturated water and chemical movement, High Plains aquifer, USA: Vadose Zone Journal, v. 6 , no. 2 , p. $533-547$.

Gutmann, M.P., 2005a, Great Plains population and environment data-Agricultural data, 1870-1997 United States: Inter-university Consortium for Political and Social Research ICPSR study number 4254, University of Michigan, Ann Arbor, Mich.

Gutmann, M.P., 2005b, Great Plains population and environment data - Social and demographic data, 1870-2000,United States: Inter-university Consortium for Political and Social Research ICPSR study number 4296, University of Michigan, Ann Arbor, Mich.

Hutson, S.S., Barber, N.L., Kenny, J.F., Linsey, K.S., Lumia, D.S., and Maupin, M.A., 2004, Estimated use of water in the United States in 2000: Reston, Va., U.S. Geological Survey Circular 1268, $46 \mathrm{p}$.

Kahle, S.C., Morgan, D.S., Welch, W.B., Ely, D.M., Hinkle, S.R., Vaccaro, J.J., and Orzol, L.L., 2011, Hydrogeologic framework and hydrologic budget components of the Columbia Plateau Regional Aquifer System, Washington, Oregon, and Idaho: U.S. Geological Survey Scientific Investigations Report 2011-5124, 66 p.

Kansas Geological Survey, 2005, Enhanced bedrock elevations estimates for the Ogallala aquifer in Kansas, accessed May 14, 2013, at http://www.kansasgis.org/ catalog/index.cfm.

Kelly, V.A., Jones, Toya, Fryar, Dennis, Dutton, A.R., and Deeds, N.E., 2010, Appendix F-northern Ogallala GAM update to support 2011 State Water Plan: Texas Water Development Board, 109 p., accessed May 14, 2013 at http://www.twdb.state.tx.us/groundwater/models/gam/ ogll_n/Appendix $\% 20 \mathrm{~F} \% 20$ \%20Update $\% 20$ Northern $\% 20$ Ogallala\%20GAM.pdf.

Loveland, T.R., Sohl, T.L., Stehman, S.V., Gallant, A.L., Sayler, K.L., Napton, D.E., 2002. A strategy for estimating the rates of recent United States land-cover changes: Photogrammetric Engineering and Remote Sensing, v. 68, p. 1091-1099.
Luckey, R.R., and Becker, M.F., 1999, Hydrogeology, water use, and simulation of flow in the High Plains aquifer in northwestern Oklahoma, southwestern Kansas, and northwestern Texas: U.S. Geological Survey WaterResources Investigations Report 99-4104, 68 p., accessed August 25, 2010, at http://pubs.usgs.gov/wri/wri994104/ pdf/wri994104.pdf.

Maupin, M.A., and Barber, N.L., 2005, Estimated withdrawals from principal aquifers in the United States, 2000: U.S. Geological Survey Circular 1279, 46 p.

McGuire, V.L., 2011, Water-level changes in the High Plains aquifer, predevelopment to 2009, 2007-08, and 2008-09 and changes in water in storage, predevelopment to 2009: U.S. Geological Survey Scientific Investigations Report 2011-5089, 13 p., accessed May 14, 2013 at http://pubs. usgs.gov/sir/2011/5089/.

McMahon, P.B., Dennehy, K.F., Bruce, B.W., Gurdak, J.J., and Qi, S.L., 2007, Water-quality assessment of the High Plains aquifer, 1999-2004: U.S. Geological Survey Professional Paper 1749, 136 p. (Also available at http://pubs.usgs.gov/ $\mathrm{pp} / 1749 /$.

Nakicenovic, Nebojsa, Alcamo, Joseph, Davis, Gerald, de Vries, Bert, Fenhann, Joergen, Gaffin, Stuart, Gregory, Kenneth, Grübler, Arnulf., Jung, T.Y., Kram, Tom, La Rovere, E.L., Michaelis, Laurie, Mori, Shunsuke, Morita, Tsuneyuki, Pepper, William, Pitcher, Hugh, Price, Lynn, Riahi, Keywan, Roehrl, Alexander, Rogner, HansHolger, Sankovski, Alexei, Schlesinger, Michael, Shukla, Priyadarshi, Smith, Steven, Swart, Robert, van Rooijen, Sascha, Victor, Nadejda, Dadi, Zhou, 2000, Special report on emissions scenarios: Cambridge, Cambridge University Press, 599 p.

Nebraska Department of Natural Resources, 2012, Department of Natural Resources Stream Gaging Data Bank: accessed May 14, 2013, at http://dnr.ne.gov/docs/ hydrologic.html.

Senay, G.B., Budde, Michael, Verdin, J.P., and Melesse, A.M., 2007, A coupled remote sensing and simplified surface energy balance approach to estimate actual evapotranspiration from irrigated fields: Sensors 7, no. 6, 979-1000.

Shah, S.D., and Houston, N.A., 2007, Geologic and hydrogeologic information for a geodatabase for the Brazos River alluvium aquifer, Bosque County to Fort Bend County, Texas (version 3): U.S. Geological Survey OpenFile Report 2007-1031, 10 p.

Sohl, T.L., Sayler, K.L., 2008, Using the FORE-SCE model to project land-cover change in the southeastern United States: Ecological Modeling, v. 219, no. 1-2, p. 49-65. 
Sohl, T.L., Sayler, K.L., Drummond, M.A., Loveland, T.R., 2007, The FORE-SCE model-A practical approach for projecting land use change using scenario-based modeling: Journal of Land Use Science, v. 2, p. 103-126.

Stanton, J.S., Peterson, S.M., Fienen, M.N., 2010, Simulation of groundwater flow and effects of groundwater irrigation on stream base flow in the Elkhorn and Loup River Basins, Nebraska, 1895-2055-Phase two: U.S. Geological Survey Scientific Investigations Report 2010-5149, 78 p. with app.

Stanton, J.S., Qi, S.L., Ryter, D.W., Falk, S.E., Houston, N.A., Peterson, S.M., Westenbroek, S.M., and Christenson, S.C., 2011, Selected approaches to estimate water-budget components of the High Plains, 1940 through 1949 and 2000 through 2009: U.S. Geological Survey Scientific Investigations Report 2011-5183, 79 p.

U.S. Department of Agriculture, National Agricultural Statistics Service, 2008, Cropland data layer: Washington, D.C.: U.S. Department of Agriculture National Agricultural Statistics Service accessed May 14, 2013, at http:// datagateway.nrcs.usda.gov/.

U.S. Environmental Protection Agency, 2012, National Hydrography Dataset Plus - NHDPlus, edition 2.1: accessed April 20, 2012, at http://www.horizon-systems. com/NHDPlus/NHDPlusV2_home.php.
U.S. Geological Survey, 2012, USGS streamflow data for Nebraska: U.S. Geological Survey National Water Information System (NWIS) database, accessed May 14, 2013, at http://waterdata.usgs.gov/ne/nwis/sw.

Walkenbach, John, 2007, Excel 2007 bible: Indianapolis, Ind.,Wiley, 866 p.

Wahl, K.L., and Wahl, T.L., 2007, BFI-A computer program for determining an index to base flow, version 4.15: Bureau of Reclamation software release, accessed May 14, 2013, at http://www.usbr.gov/pmts/hydraulics_lab/twahl/bfi/.

Weeks, J.B., Gutentag, E.D., Heimes, F.J., and Luckey, R.R., 1988, Summary of the High Plains Regional AquiferSystem Analysis in parts of Colorado, Kansas, Nebraska, New Mexico, Oklahoma, South Dakota, Texas, and Wyoming: U.S. Geological Survey Professional Paper 1400-A, $30 \mathrm{p}$.

Westenbroek, S.M., Kelson, V.A., Dripps, W.R., Hunt, R.J., and Bradbury, K.R., 2010, SWB-A modified ThornthwaiteMather Soil-Water-Balance code for estimating groundwater recharge: U.S. Geological Survey Techniques and Methods 6,-A31, 60 p., accessed May 14, 2013, at http://pubs.usgs. gov/tm/tm6-a31/tm6a31.pdf.
Publishing support provided by

Lafayette Publishing Service Center
Information regarding water resources in Texas is available at

http://tx.usgs.gov/ 


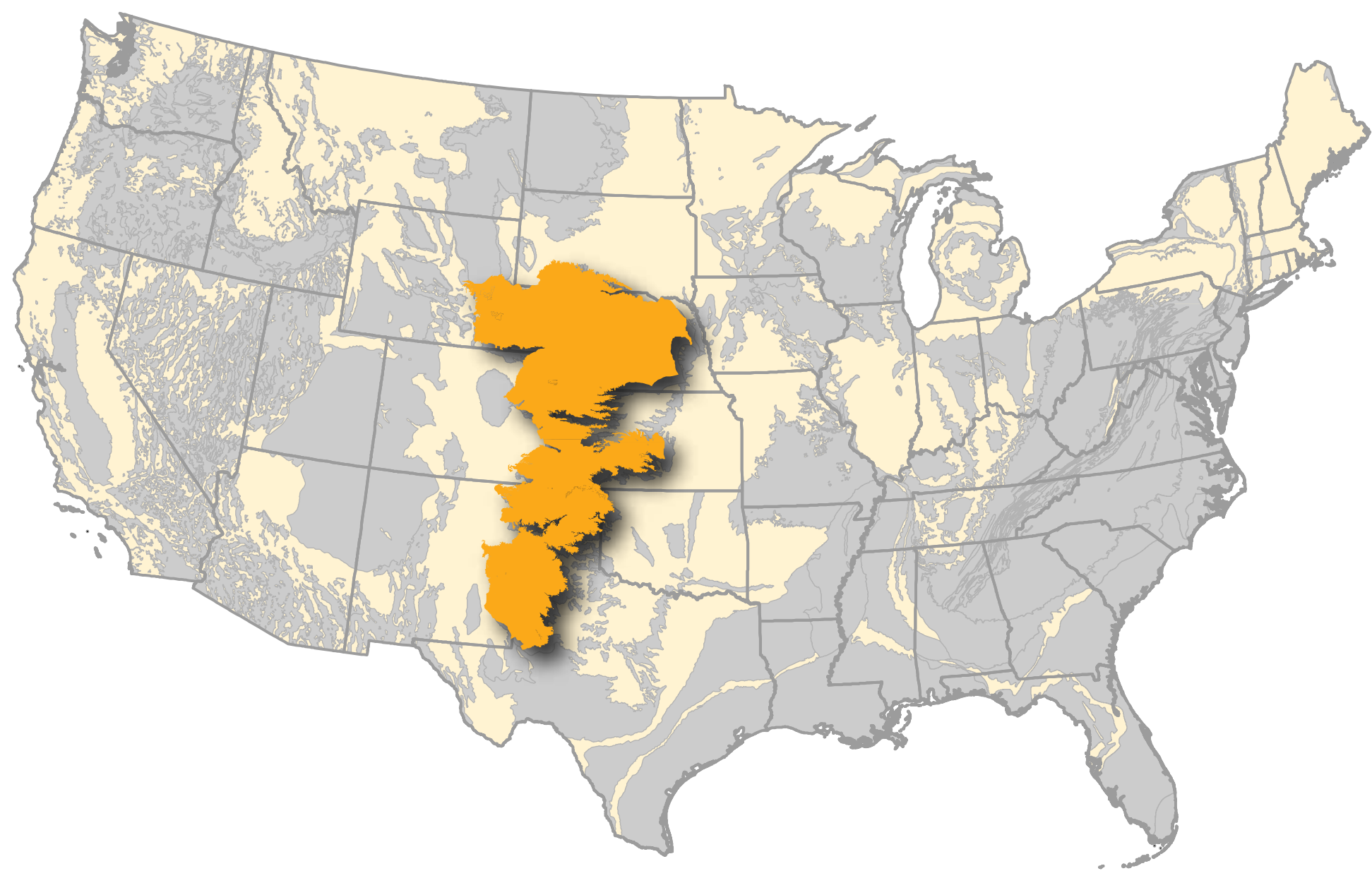

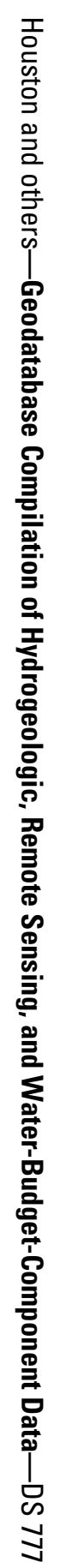

